Guex-Holzer, S. \& Tomcsik, J. (1956). J. gen. Microbiol. 14, 14-25

\title{
The Isolation and Chemical Nature of Capsular and Cell-wall Haptens in a Bacillus Species
}

\author{
By S. GUEX-HOLZER AND J. TOMCSIK \\ Institute for Hygiene and Bacteriology, University of Basel, Switzerland
}

SUMMARY: By extracting the capsular material of Bacillus $\mathrm{M}$ with hot water, D-glutamic acid polypeptide and a polysaccharide were isolated. The polypeptide absorbs the antibody from an anthrax immune serum, which reveals a homogenously distributed capsular material in Bacillus $\mathrm{M}$. The polysaccharide absorbs one of the homologous antibodies, which renders a characteristic structure visible in the capsule and gives a specific cell-wall reaction. By using lysozyme digestion for the dissolution of the capsule or of the cell-wall a mucoprotein was isolated. The mucoprotein gives serological reactions identical with those of the polysaccharide, and it corresponds to a less degraded form of the cellular substance participating in building up both the cell wall and the capsular structure.

We have shown that a morphologically and chemically complex structure can be demonstrated, by the use of appropriate antibodies, in the capsule of Bacillus megaterium and the related Bacillus M (Tomcsik, 1951; Tomesik \& Guex-Holzer, 1951, 1954 , $c$ ). Anthrax D-glutamic polypeptide antibody made visible homogenously distributed material in phase-contrast. The homologous immune serum revealed polar bodies and conspicuous transverse septa in the capsule. It was shown at the initial stage of lysozyme digestion that the capsular transverse septa appeared as a direct continuation of the cross cell walls and that the homologous serum also enhanced the visibility of the cell wall. A similar specific cell-wall reaction was also demonstrated by adding the same serum to trypsin-treated or to autolysed bacteria. Our previous work indicated that the antibody reacting with both the capsular transverse septa and the cell wall can be absorbed by material composed mainly of polysaccharide. The purpose of the present paper is to describe two methods for the isolation of a polysaccharide and of a mucoprotein. These substances contain an immunologically active component and appear to absorb the antibody responsible for both reactions.

The capsular material was extracted simply by boiling an aqueous suspension of the bacteria. A similar method was used for the extraction of polysaccharides by Webb (1948) working with Staphylococcus citreus, and by Aubert (1949) with capsulated Bacillus megaterium. In the hot-water extract of capsulated Bacillus $\mathbf{M}$ both D-glutamic acid polypeptide and a polysaccharide were found. For the separation of these two substances a method different from those described previously (Tomesik \& Szongott, 1933; Ivanovics \& Brückner, 1937; Hanby \& Rydon, 1946) was used.

The extraction of serologically active material from non-capsulated Bacillus M was extremely difficult. Alkalies, acids, sodium taurocholate, 
phenol, formamide or antiformin were tried without success; extracts exhibited only slight serological activity. Previous observations in the literature suggested to us the use of lysozyme for extraction. We found (Tomcsik \& Guex-Holzer, 1952) with phase-contrast that lysozyme dissolved the cell walls and the capsular structures of Bacillus $M$ within a short time without destroying the cytoplasmic membrane. Salton (1952a) reported, simultaneously, that lysozyme dissolved the mechanically separated cell walls of Micrococcus lysodeikticus.

\section{METHODS}

Preparation of organisms. The strain of Bacillus $\mathbf{M}$ used in this work invariably grew on Gladstone \& Fildes CCY agar in capsulated form without the addition of glucose. Kolle flasks containing $70 \mathrm{ml}$. agar were inoculated from a $12 \mathrm{hr}$. agar culture. The flasks were incubated for $20 \mathrm{hr}$. at $32^{\circ}$; the organisms were suspended in tap water and the suspension filtered through gauze. The average dry weight of organisms from one Kolle flask was $0 \cdot 27 \mathrm{~g}$. Noncapsulated bacilli were obtained in Gladstone \& Fildes liquid medium aerated for $24-48 \mathrm{hr}$. at $30^{\circ}$. The growth from liquid medium was washed twice with tap water in a Sharples centrifuge.

Cell-wall preparations were made by digesting a living suspension of bacteria with trypsin (Siegfried, Zofingen), $5 \mathrm{mg} . / \mathrm{ml}$. at $37^{\circ}$ for $15 \mathrm{hr}$.

Immune sera. An immune serum produced by fifteen intravenous injections of heat-killed capsulated Bacillus anthracis in rabbits is referred to in this work as 'polypeptide antibody', since only the $\mathrm{D}$-glutamic acid polypeptide antibody of the anthrax serum reacted with Bacillus $\mathbf{M}$. The homologous antibody was produced by ten injections of living Bacillus $\mathrm{M}$ suspensions in rabbits.

Specific capsule and cell-wall reactions were carried out with immune sera as described previously (Tomcsik \& Guex-Holzer, 1954b).

Precipitin reaction was performed in capillary tubes by layering serial dilutions of extract on undiluted immune serum. This controlled the efficiency of the major steps in the fractionation.

Hydrolysis. The glutamic acid polypeptide was hydrolysed with $6 \mathrm{~N}-\mathrm{HCl}$ under reflux for $15 \mathrm{hr}$. The mucoprotein and the polysaccharide were hydrolysed with $2 \mathrm{~N}-\mathrm{HCl}$ for $1.5 \mathrm{hr}$. for determination of reducing substances and with $6 \mathrm{~N}-\mathrm{HCl}$ for $15 \mathrm{hr}$. for paper chromatography.

Paper chromatography. Phenol and collidine were used as solvents. The spray reagents were ninhydrin for amino acids and amino sugars, $p$-dimethylamino-benzaldehyde for amino sugars, aniline hydrogen phthalate for reducing and for some non-reducing sugars and naphthoresorcinol for non-reducing sugars. The hydrolysate was placed on Whatman filter-paper no. 1. The method used in two-dimensional chromatograms to compare the $\boldsymbol{R}_{F}$ value of an unknown substance with that of the standard substance was the following: when, for example, the presence of glucosamine had to be tested, the hydrolysate was deposited on the left lower corner of a filter-paper, whereas the standard glucosamine solution was applied at the right lower and left upper corners. The paper was treated in one direction with phenol, in another 
with collidine, then sprayed. Straight lines drawn through the spots of the standard substance indicated at their intersection the place where the spot of an identical substance of the hydrolysate should be located. With this method we could differentiate the control spots of glucosamine and galactosamine.

Total nitrogen was estimated by the method of Koch \& McMeekin (1924), phosphorus by the method of Fiske \& Subbarow (1925) and reducing sugars by the method of Folin \& Wu (1920); reducing power was expressed as glucose. The colorimetric readings for these estimations were performed in a KlettSummerson colorimeter.

Acetyl estimation was by the method of Freudenberg \& Weber (1925).

Lysozyme was prepared from egg-white following the procedure of Alderton $\&$ Fevold (1946). For comparison a purified lysozyme preparation of Mann Research Laboratories was used.

\section{RESULTS \\ Hot-water extraction of capsulated bacteria}

Capsulated bacteria (dry weight $14 \mathrm{~g}$.) were suspended in $1200 \mathrm{ml}$. tap water, shaken with $10 \mathrm{ml}$. chloroform and kept at room temperature overnight. The capsules seemed to be intact and showed a large volume in indian ink preparation (Pl. 1, fig. 1). The suspension was then heated in a bath of boiling water for $4 \mathrm{hr}$. During this procedure the capsules became successively thinner (Pl. 1, figs. 2, 3) but they were detected even after $4 \mathrm{hr}$. in c. 50\% of the bacteria. More prolonged heating did not result in appreciable further extraction. The bacteria were then centrifuged down and washed twice. The mixed yellowish brown, somewhat turbid supernatants $(1100 \mathrm{ml}$.) were concentrated at $60^{\circ}$ in vacuo to $200 \mathrm{ml}$., centrifuged and the almost clear supernatant precipitated with $500 \mathrm{ml} .96 \%(\mathrm{v} / \mathrm{v})$ ethanol in water. (When not stated otherwise ethanol means $96 \%(\mathrm{v} / \mathrm{v})$ ethanol in water.)

The weight of the ethanol precipitate was $3.5 \mathrm{~g} .(25 \%(\mathrm{w} / \mathrm{w})$ of the dried bacteria) and when dissolved in $100 \mathrm{ml}$. water, the resulting solution was somewhat turbid, very viscous and gave a strong precipitation reaction with the polypeptide antiserum as well as with the homologous immune serum. By addition of 0.7 vol. ethanol an almost inactive substance was brought down and discarded. A rough separation of two substances giving different serological reactions was attained by fractional precipitation with ethanol; $1 \cdot 1$ vol. ethanol brought down the bulk of the substance (fraction A) which reacted with polypeptide antibody; $2.5 \mathrm{vol}$. ethanol precipitated fraction $\mathrm{B}$ which reacted mainly with the homologous antibody.

\section{Isolation of D-glutamic acid polypeptide from fraction $A$}

Among the substances contained in fraction $\mathbf{A}$ were inactive proteins and some bacteria which were not separated during centrifugation of the strongly viscous solution. Inactive proteins were removed by dialysis after digestion with trypsin. Trypsin also digested the bacteria with the exception of the cell walls and some other residual substances which were precipitated with barium acetate. 
Fraction $\mathrm{A}$ was dissolved in $130 \mathrm{ml} . \mathbf{0} \cdot 85 \% \mathrm{NaCl}$ and digested with $20 \mathrm{mg}$. trypsin $\left(\mathrm{pH} 8\right.$ ) at $37^{\circ}$ for $24 \mathrm{hr}$. To prevent contamination $3.5 \mathrm{ml}$. chloroform was added and the $\mathrm{pH}$ value readjusted from time to time with $\mathrm{NaOH}$. Barium acetate $\left(200 \mathrm{mg}\right.$.) was then added and the solution was rapidly heated to $100^{\circ}$. The coagulated material, including trypsin, was centrifuged down. The digested proteins were removed by dialysis for 2 days. The polypeptide was precipitated from $150 \mathrm{ml}$. dialysed solution by the addition of sodium acetate and $120 \mathrm{ml}$. ethanol. This procedure was repeated twice and the precipitate freeze-dried after 2 days dialysis in distilled water. A total of $685 \mathrm{mg}$. of readily water soluble polypeptide material was obtained, amounting to $4.5 \%(w / w)$ of the bacteria.

\section{Isolation of the capsular polysaccharide from fraction $B$}

The serologically inactive substances of fraction $\mathbf{B}$ which were difficult to remove by the usual methods of purification, formed insoluble compounds with several proteins at acid reaction. We assumed that this reaction might be similar to the one we described between capsular substances and proteins (Tomcsik \& Guex-Holzer, 1954a), being probably elicited at a $\mathrm{pH}$ value lying between the isoelectric points of the two reacting substances. Indeed it was observed that the glutamic acid polypeptide, an acidic substance, was precipitated by bovine albumin at $\mathrm{pH} \mathrm{3-4.5}$, when the basic groups of albumin were dissociated. In eliminating the impurities of fraction $\mathrm{B}$ we used bovine plasma albumin fraction $\mathrm{V}$ (Armour and Co. Ltd., London) at an appropriate $\mathrm{pH}$ value.

Fraction B was dissolved in $100 \mathrm{ml}$. MeIlvain's buffer solution (pH 3.2), and while shaking $5 \%(\mathrm{w} / \mathrm{v})$ albumin was added until maximum turbidity was obtained. The resulting granular precipitate was easily removed in the centrifuge, and, when dissolved by adjusting to $\mathrm{pH} 7$, gave no reaction with the homologous immune serum.

It was occasionally observed that the precipitate obtained after the addition of protein at $\mathrm{pH} 3.2$ could not be fully separated. However, by altering the $\mathrm{pH}$ in an appropriate direction flocculation of the turbid suspension could be effected. Different impurities probably require different $\mathrm{pH}$ optima to form insoluble compounds with the protein added. It was sometimes necessary to change the $\mathrm{pH}$ value several times to eliminate all impurities which reacted with proteins. This method can be used for purification of bacterial extracts only when the substance to be isolated is not involved in the reaction.

The precipitated protein compound was washed with buffer at $\mathrm{pH} 3 \cdot 2$. The clear colourless supernatant fluids were combined and neutralized with $\mathrm{N}-\mathrm{NaOH}$. At pH $4 \cdot 8$, at the isoelectric point of the albumin, the solution became cloudy. When $450 \mathrm{ml}$. ethanol were added to the $250 \mathrm{ml}$. solution the rest of the albumin was largely precipitated. After addition of $750 \mathrm{ml}$. ethanol a polysaccharide containing a serologically active fraction was precipitated. This fraction was deproteinized by Sevag's method (1951) and after ethanol fractionation was dissolved in formamide. From the formamide solution a small amount of inactive substance was precipitated by ethanol. The polysaccharide was dissolved in distilled water and precipitated with 
0.5 vol. ethanol without the addition of sodium acetate. This procedure was repeated and the substance freeze-dried. Dialysis was omitted since in previous experiments it led to loss of material. Polysaccharide (71 mg.) was obtained as a white powder, easily soluble in water.

\section{Extraction of capsulated bacteria with lysozyme and isolation of a mucoprotein}

Capsulated bacteria (15 g.) were suspended in $70 \mathrm{ml} .0 \cdot 85 \% \mathrm{NaCl}$. The suspension was placed in a $60^{\circ}$ water-bath for $30 \mathrm{~min}$.; lysozyme (4 mg.) was then added, and after shaking the mixture was incubated at $45^{\circ}$. The suspension was examined frequently by phase-contrast microscope for dissolution of capsules. After about $30 \mathrm{~min}$. the capsules were no longer visible. To prevent a visible dissolution of the cell walls, the suspension was immediately chilled and spun in a Sharples centrifuge. The supernatant was deproteinized according to Sevag's method. After drying in vacuo at $60^{\circ} 1.5 \mathrm{~g}$. of material was recovered which gave a clear solution in $200 \mathrm{ml} .0 .85 \% \mathrm{NaCl}$. It gave equally strong serological reactions with the homologous immune serum as well as with polypeptide antibody. The polypeptide was eliminated by fractional ethanol precipitation as described previously (see hot-water extraction procedure). Further purification of the mucoprotein fraction was carried out by precipitating the substance with $96 \%$ ethanol saturated with sodium acetate, first from formamide solution, then from solution in saturated urea. When by a repetition of these procedures no more serologically-inactive substances were removed, the distilled water solution of the material was dialysed and freeze-dried.

Mucoprotein (340 mg.) in the form of a white powder very easily soluble in water was thus obtained from the lysozyme extract of capsulated bacteria. The serological activity of this material with the homologous immune serum was about the same as that of the polysaccharide purified after hot-water extraction. It did not react with polypeptide antibody. It should be pointed out that by the lysozyme method about five times more serologically active material could be obtained than by hot-water extraction.

\section{Extraction of non-capsulated bacteria with lysozyme and isolation of a cell-wall mucoprotein}

As shown previously (Tomcsik \& Guex-Holzer, 1952; Salton, 1952a) the cell wall of Bacillus $\mathbf{M}$ can also be dissolved within a short time when an appropriate concentration of lysozyme is applied. Several batches of bacteria were treated with lysozyme for the isolation of purified cell-wall mucoprotein. The method of isolation is illustrated here with one example.

Non-capsulated bacteria (2 g.) were suspended in $40 \mathrm{ml} .0 .85 \% \mathrm{NaCl}$ and placed for $30 \mathrm{~min}$. in a $60^{\circ}$ water-bath. The suspension was then chilled, $5 \mathrm{mg}$. lysozyme added and shaken without glass beads for $15 \mathrm{~min}$. in a Mickle vibrator to ensure a homogenous distribution and the absorption of lysozyme. Free lysozyme was removed by centrifugation. The bacteria treated with 
lysozyme treated bacteria were suspended in $50 \mathrm{ml} . \mathbf{0 . 8 5} \% \mathrm{NaCl}$ and placed in a $35^{\circ}$ water-bath for $2 \mathrm{hr}$.

At this stage phase-contrast microscopy revealed only partially degraded 'small bacteria' but no cell walls. To prevent a further disintegration of mucoprotein, the suspension was chilled and centrifuged. The sediment was washed twice in $\mathbf{0 . 8 5} \% \mathrm{NaCl}$, after which it was shaken for a short time in a Mickle vibrator to facilitate resuspension.

The washing fluids and extract were mixed and fractionated further with essentially the same procedure as used for the purification of the capsular mucoprotein. Slight modifications were, however, occasionally necessary, probably owing to the different substances extracted from the cell wall. Fifty mg. mucoprotein were obtained $(2 \cdot 5 \%(\mathrm{w} / \mathrm{w})$ of the bacteria). The yield was proportionately the same as by the much less intensive lysozyme extraction of capsulated bacteria. The appearance and the solubility of the cell-wall mucoprotein were similar to those of the 'capsular' mucoprotein.

\section{Properties of the isolated substances}

The data of the serological properties and chemical analysis of hot-water extracts in different stages of purification are summarized in Table 1. As can be seen the polypeptide of fraction $\mathbf{A}$ was precipitated without admixture of polysaccharides by adding $1 \cdot 1$ vol. ethanol to the raw extract. Fraction B

Table 1. Isolation of D-glutamic acid polypeptide and of a polysaccharide by hot-zeater extraction of capsulated bacilli

\begin{tabular}{|c|c|c|c|c|c|c|}
\hline \multirow[b]{2}{*}{ Fraction } & \multirow[b]{2}{*}{$\begin{array}{l}\text { Weight } \\
\text { (mg.) }\end{array}$} & \multicolumn{2}{|c|}{ Precipitin titre } & \multirow[b]{2}{*}{$\begin{array}{l}\mathbf{N} \\
(\%)\end{array}$} & \multirow[b]{2}{*}{$\begin{array}{c}\mathbf{P} \\
(\%)\end{array}$} & \multirow[b]{2}{*}{$\begin{array}{c}\text { Reducing } \\
\text { substance } \\
(\%)\end{array}$} \\
\hline & & $\begin{array}{l}\text { Polypeptide } \\
\text { antibody }\end{array}$ & $\begin{array}{l}\text { Homologous } \\
\text { serum* }\end{array}$ & & & \\
\hline Raw extract & 3550 & $5 \times 10^{5}$ & $1 \times 10^{5}$ & $4 \cdot 3$ & $6 \cdot 3$ & n.t. \\
\hline Fraction A & 1375 & $1 \times 10^{6}$ & - & 6.9 & $\mathbf{5 \cdot 3}$ & n.t. \\
\hline Fraction B & 1150 & $5 \times 10^{4}$ & $2 \times 10^{5}$ & $2 \cdot 6$ & 8 & n.t. \\
\hline $\begin{array}{l}\text { Polypeptide from } \\
\text { fraction A }\end{array}$ & 685 & $2 \times 10^{6}$ & - & 10 & - & - \\
\hline $\begin{array}{l}\text { Polysaceharide from } \\
\text { fraction B }\end{array}$ & 71 & - & $2 \times 10^{6}$ & 4 & 0.5 & 40 \\
\hline
\end{tabular}

- = negative; n.t. = not tested.

* Antiserum to capsulated Bacillus M.

contained, however, apart from the polysaccharide, an appreciable amount of polypeptide as well as serologically inactive substances. These substances could be eliminated during the course of subsequent fractionation with partial loss of the polysaccharide fraction.

The properties of the mucoprotein obtained with lysozyme extraction of capsulated bacteria are given in Table 2. Serological and chemical analysis of the capsular and cell-wall mucoproteins revealed no essential difference between the two substances. Both of them failed to give precipitation with anthrax polypeptide antibody, and apparently they precipitated the same 
antibody of the homologous immune serum. Furthermore their serological reactions were identical with those of the polysaccharide. It should, however, be noted that whereas the precipitin titre of the polysaccharide isolated from the hot-water extract of capsulated bacteria remained stable, the titre obtained with the mucoproteins started to decrease within a few days of their isolation. Within 1 or 2 months the serological activity of the mucoproteins, isolated after enzymic digestion of the capsule or of the cell wall, decreased to at least one-tenth of the original value even when they were kept at $4^{\circ}$ after freeze-drying.

Table 2. Characteristics of the capsular and cell-wall mucoprotein

\begin{tabular}{|c|c|c|c|c|c|c|c|}
\hline Substance & $\begin{array}{c}\text { Initial } \\
\text { weight of } \\
\text { bacteria } \\
\text { (g.) }\end{array}$ & $\begin{array}{l}\text { Weight of } \\
\text { purified } \\
\text { substance } \\
\text { (mg.) }\end{array}$ & $\begin{array}{l}\text { Precipitin } \\
\text { titre with } \\
\text { homologous } \\
\text { serum }\end{array}$ & $\begin{array}{c}\mathbf{N} \\
(\%)\end{array}$ & $\begin{array}{c}\mathbf{P} \\
(\%)\end{array}$ & $\begin{array}{c}\text { Reducing } \\
\text { substance } \\
(\%)\end{array}$ & $\begin{array}{c}\text { Acetyl } \\
(\%)\end{array}$ \\
\hline $\begin{array}{l}\text { Capsular } \\
\text { mucoprotein }\end{array}$ & 15 & 340 & $1 \times 10^{6}$ & $7 \cdot 8$ & $4 \cdot 1$ & $22 \cdot 5$ & $4 \cdot 3$ \\
\hline $\begin{array}{l}\text { Cell-wall } \\
\text { mucoprotein }\end{array}$ & 2 & 50 & $1 \times 10^{6}$ & $7 \cdot 6$ & $4 \cdot 7$ & 18 & n.t. \\
\hline
\end{tabular}

Further information about the chemical nature of the isolated haptens after their hydrolysis (see Methods) was obtained through paper chromatography.

Only glutamic acid was found in our capsular polypeptide preparation when smaller amounts of hydrolysate were placed on the paper. However, by depositing 50-100 $\mu \mathrm{g}$. of the hydrolysed polypeptide a second faint spot appeared after ninhydrin spraying, corresponding to no. 6 on Fig. 2.

The result of analysis of the capsular polysaccharide is shown in the twodimensional chromatogram after spraying with $p$-dimethylaminobenzaldehyde in Fig. 1. Galactosamine and glucosamine were identified by using standard substances for control. The spot no. 3 was very weak. It reacted like an amino sugar with ninhydrin, with aniline hydrogen phthalate and with $p$ dimethylaminobenzaldehyde. It showed, however, no reducing power when tested in the following way:

Equal sized paper strips of the collidine chromatogram were cut out, each containing a separate spot and were extracted. Extracts of glucosamine showed reducing power, the extract of spot no. 3 did not.

Hot-water extraction and chromatographic analysis of the purified polysaccharide were carried out several times. Results showed a variation between the ratio of the glucosamine to galactosamine, probably in accordance with slight variation in the synthesizing capacity of the strain. During the first period glucosamine, later galactosamine predominated in the hydrolysed polysaccharide. This difference is noted while admitting that the differentiation of glucosamine and galactosamine by two-dimensional chromatography with phenol and collidine solvents does not give an assured means of identification.

Chromatographic analysis of the capsular and cell-wall mucoprotein showed the same results independent of their source. Results obtained in the two- 


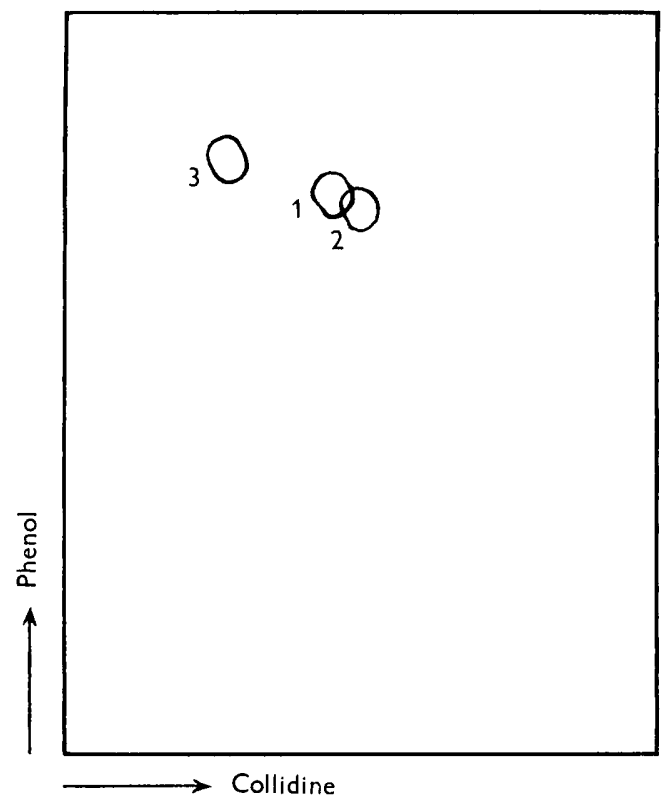

Fig. 1. Chromatogram of hydrolysed capsular polysaccharide sprayed with $p$-dimethylaminobenzaldehyde. 1, galactosamine; 2 , glucosamine; 3 , see text.

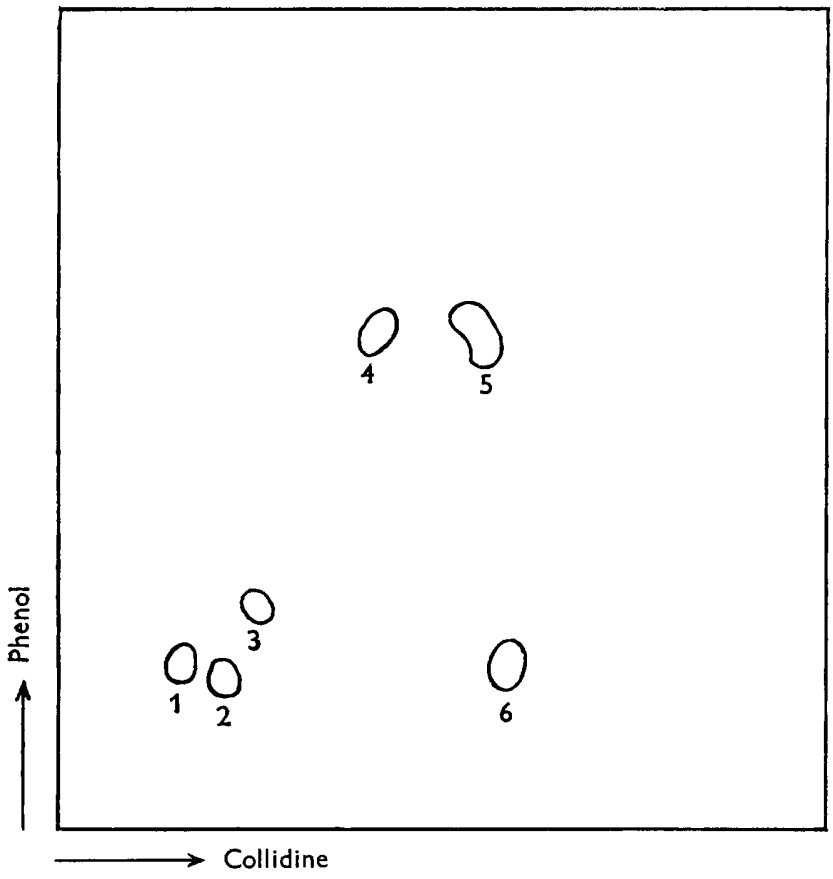

Fig. 2. Chromatogram of hydrolysed mucoprotein sprayed with ninhydrin. 1, diaminopimelic acid; 3 , glutamic acid; 4, alanine; 5 , hexosamine; 2,6 , see text. 
dimensional chromatogram are shown in Fig. 2. Hexosamine was found constantly in all of the mucoprotein hydrolysates but sometimes glucosamine, at other times galactosamine, seemed to predominate. Alanine occurred also in all of the preparations but its spots were of varying intensity. Glutamic acid spots were always very pale. Presence of diaminopimelic acid was assumed only on the basis of $R_{F}$ value; it was, however, not controlled with a standard preparation. The non-identified spot no. 2 reacted strongly with ninhydrin; in a mixed preparation its $\boldsymbol{R}_{\boldsymbol{F}}$ value was slightly different from aspartic acid; similarly, the non-identified spot no. 6 was found only occasionally in different mucoprotein preparations, but it could be demonstrated regularly in polypeptide preparations when a larger quantity of hydrolysate was placed on the paper. This spot gave a very faint bluish-grey colour with ninhydrin, and it corresponds probably to the unknown hexosamine in spore peptides reported by Strange \& Powell (1954).

\section{Reactions of immune sera after absorption with specific substances}

It was easily established that the capsular polypeptide did not show any serological relationship, either with the capsular polysaccharide or the mucoproteins. On the other hand, the mucoproteins isolated from capsulated and non-capsulated bacteria were serologically and chemically identical, and they contained the same hapten as the capsular polysaccharide. Since the last-mentioned substances were identical in their direct serological reactions as well as in their capacity of absorption, we have summarized in Table 3 only the polypeptide and polysaccharide absorptions.

Table 3. Absorption of sera by capsular polypeptide and polysaccharide

Antibody
Anthrax-polypeptide
Anthrax-polypeptide
Anthrax-polypeptide
Homologous serum
Homologous serum
Homologous serum
Homologous serum
Homologous serum
Homologous serum
Homologous serum
Homologous serum
Homologous serum
Homologous serum

Hapten used
for absorption
Polypeptide
Polysaccharide
Polypeptide
Polysaccharide
Polypeptide
Polysaccharide
Polysaccharide
-

$\quad$ Reaction
Visibility of capsule
Visibility of capsule
Visibility of capsule
Visibility of capsular structure
Visibility of capsular structure
Visibility of capsular structure
Specific cell-wall reaction
Specific cell-wall reaction
Specific cell-wall reaction
Agglutination of living bacteria
Agglutination of living bacteria
Agglutination of cell-wall
preparation
Agglutination of cell-wall
preparation

Since the specific capsular and cell-wall reactions could not be elicited even with the best immune serum when this was diluted more than $1: 30$, absorption for these reactions was carried out by mixing equal volumes of the undiluted immune sera and a $1: 200(\mathrm{w} / \mathrm{v})$ dilution of the specific substances. 
This mixture contained a large antigen surplus and precipitation was inhibited. The mixtures were kept first $30 \mathrm{~min}$. at $37^{\circ}$ and subsequently for 5 hr. at $4^{\circ}$.

As higher dilutions resulted in agglutination 1 vol. of serum was absorbed with 9 vol. of $1: 2000(\mathrm{w} / \mathrm{v})$ dilution of the hapten before carrying out the agglutination tests. No specific capsular reaction was obtained with homologous serum after its absorption with polysaccharide (Pl. 1, fig. 4). The nonabsorbed homologous serum, or the same serum after polypeptide treatment, revealed the capsular transverse septa ( $\mathrm{Pl} .1$, fig. 5), whereas successive addition of an anthrax polypeptide antibody made the homogeneously distributed capsular material visible (PI. 1, fig. 6). The last-mentioned reaction was not influenced by adding polysaccharide to immune serum; it could not, however, be obtained after polypeptide absorption of this serum.

The results of agglutination tests with absorbed sera listed in Table 3 require special comment. The agglutinin titre of homologous serum against living bacteria was but slightly decreased after polysaccharide adsorption, whereas the absorbed serum did not agglutinate the cell-wall preparations in an essentially higher titre than a normal serum. In another communication we have reported that the homologous immune serum contains, apart from the polysaccharide antibody, a protein antibody which reacts in the agglutination test with a thermolabile surface antigen not present in the cell-wall preparations obtained by trypsin digestion of the bacteria (Tomesik \& Guex-Holzer, 1954d).

\section{DISCUSSION}

We assume that the specific substances isolated and characterized in this work are homogeneous. We base this assumption on the observation that various methods of fractionation did not reveal any further change in serological activity and in the chemical composition of the purified substances. Since capsular polysaccharide and mucoprotein gave an identical serological reaction, we can safely conclude that the basis of their serological specificity is dependent on the special configuration of the substance of simpler chemical composition, i.e. of the polysaccharide. On the other hand, it can be concluded that the mucoprotein resembles more closely the composition of the specific substance as this occurs in the capsule and in the cell wall. Hot-water extraction at neutral reaction apparently splits off the polysaccharide from much more complex molecules within the cell structure. It is also probable that the mucoprotein we isolated after lysozyme extraction is a degradation product and is split off from its combination with ribonucleic acids, as can be surmised from the observation of Webb (1948). The specific polysaccharide can, therefore, be regarded as an identical component of more complex unknown substances forming on the one hand the cell wall and on the other hand the peculiar capsular structure of Bacillus M. The D-glutamic acid polypeptide occurs in the capsule but it does not contribute to the composition of the cell wall. 
Can the mucoprotein be regarded as the substrate of Bacillus $\mathbf{M}$ which is acted upon by lysozyme? Before we attempt to answer this question it should be pointed out that our knowledge about the substrate of lysozyme is based on experiments essentially different from those reported in this paper. Meyer, Palmer, Thompson \& Khorazo (1936), and Epstein \& Chain (1940) isolated polysaccharides from lysozyme-sensitive micro-organisms using methods which disintegrated the whole cellular structure. Since they found that from these polysaccharides one-third of their reducing sugars were liberated after a prolonged lysozyme digestion, they regarded the polysaccharides as the substrate of lysozyme. Feiner, Meyer \& Steinberg (1946) confirmed these observations and found that a mucopolysaccharide isolated by alkaline extraction of Micrococcus lysodeikticus retained its original serological activity after digestion with lysozyme for $1 \mathrm{hr}$. The primary purpose of the present work was quite different. It was demonstrated previously that lysozyme acts on the capsular structure and on the cell wall of Bacillus $\mathrm{M}$ and that both of these cellular elements were made visible in phase-contrast by the same immune serum (Tomesik \& Guex-Holzer, 1952). In the present work a mucoprotein and a polysaccharide were isolated, both of which absorbed the antibody, which rendered these cellular structures visible. These observations might justify the assumption that the mucoprotein corresponds more closely to the cellular substrate acted upon by lysozyme than does the purified polysaccharide. This assumption seems to us probable because the mucoprotein was extracted after lysozyme disintegration of the capsular, i.e. of the cell-wall structure and because its serological reactivity was largely inactivated when kept for 1 or 2 months at $4^{\circ}$ after freeze-drying. The natural cellular substance attacked in living bacteria by lysozyme is probably much more complex than the mucoprotein as can be surmised from the excellent studies of Salton (1952b, 1953) on the chemical composition of the isolated bacterial cell wall.

This work was carried out with the help of the Rockefeller Foundation.

\section{REFERENCES}

Alderton, G. \& Fevold, H. L. (1946). Direct crystallization of lysozyme from egg white and some crystalline salts of lysozyme. J. biol. Chem. 164, 1.

Auber', J. P. (1949). De l'existence d'un polyoside chez Bac. megatherium. C.R. Acad. Sci., Paris, 229, 477.

Epstein, L. A. \& Chain, E. (1940). Some observations on the preparation and properties of the substrate of lysozyme. Brit. J. exp. Path. 21, 339.

Feiner, R. R., Meyer, K. \& Steinberg, A. (1946). Bacterial lysis by lysozyme. J. Bact. 52, 375.

Fiske, C. H. \& Subbarow, Y. (1925). 'The colorimetric determination of phosphorus. J. biol. Chem. 66, 375.

Folin, O. \& WU, H. (1920). A simplified and improved method for determination of sugar. J. biol. Chem. 41, 367 .

Freudenberg, K. \& Weber, E. (1925). Mikroacetylbestimmung. Anger. Chem. 38, 280.

Hanby, W. E. \& Rydon, H. N. (1946). The capsular substance of Bacillus anthracis. Biochem. J. 40, 297. 
Journal of General Microbiology, Vol. 14, No. 1
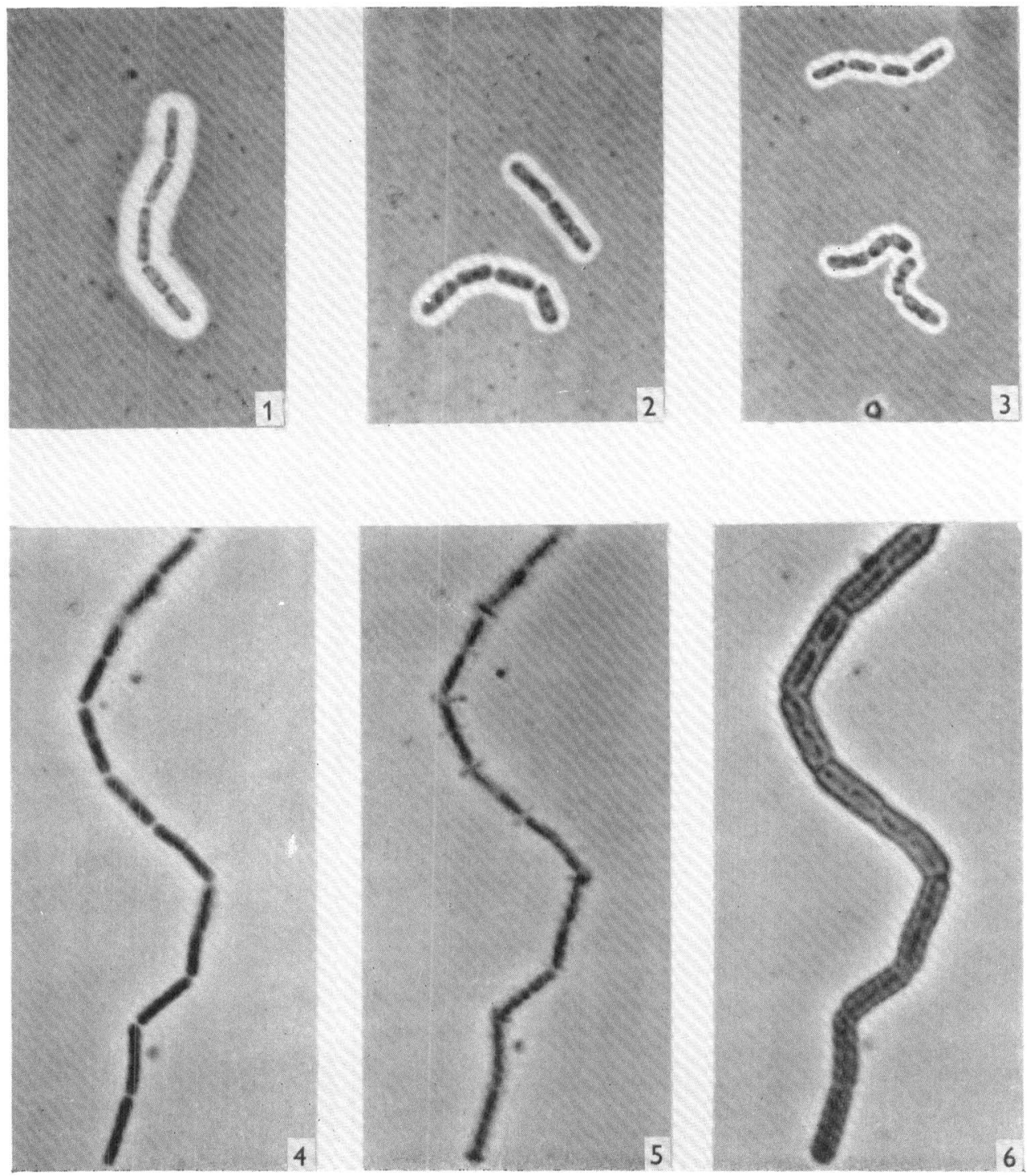

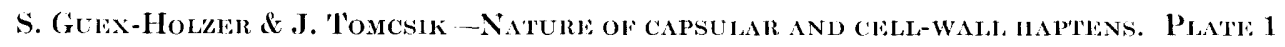


Ivanovics, G. \& Brückner, G. (1937). Chemische und immunologische Studien über den Mechanismus der Milzbrandinfektion und Immunität. Z. ImmunForsch. 90, 304.

Косн, F. C. \& McMeekin, P. L. (1924). A new direct nesslerisation microkjeldahl method and a modification of the Nessler-Folin reagent for ammonia. J. Amer. chem. Soc. 46, 2066.

Meyer, K., Palmer, J. W., Thompson, R. \& Khorazo, D. (1936). On the mechanism of lysozyme action. J. biol. Chem. 113, 479.

Salton, M. R. J. (1952a). Cell wall of Micrococcus lysodeikticus as the substrate of lysozyme. Nature, Lond. 170, 746.

Salton, M. R. J. (1952b). Studies of the bacterial cell wall. III. Preliminary investigation of the chemical constitution of the cell wall of Streptococcus faecalis Biochim. biophys. Acta, 8, 510.

Salton, M. R. J. (1953). Studies of the bacterial cell wall. IV. The composition of the cell walls of some Gram-positive and Gram-negative bacteria. Biochim. biophys. Acta, 10, 512.

SevaG, M. G. (1951). Immuno-catalysis. Springfield, Illinois, U.S.A.: Charles C. Thomas.

Strange, R. E. \& Powell, J. F. (1954). Hexosamine-containing peptides in spores of Bacillus subtilis, B. megatherium and B. cereus. Biochem. J. 58, 80.

Tomcsik, J. (1951). Complex structure of the bacterial capsule in the genus Bacillus. Experientia, 7, 459.

Toмcsik, J. \& Guex-Holzer, S. (1951). Anthrax-Polypeptid und andere speziesspezifische Substanzen der Kapsel in der Bazillus-Gruppe. Schweiz. Z. Path. 14, 515.

Tomcsik, J. \& Guex-Holzer, S. (1952). Änderung der Struktur der Bakterienzelle im Verlauf der Lysozym-Einwirkung. Schweiz. Z. Path. 15, 517.

Tomcsiк, J. \& Guex-Holzer, S. (1954a). Demonstration of the bacterial capsule by means of a pH-dependent, salt-like combination with proteins. J. gen. Microbiol. 10,97 .

Tomcsik, J. \& Guex-Holzer, S. (1954 b). A specific cell wall reaction in Bacillus sp. J. gen. Microbiol. 10, 317.

Tomcsik, J. \& Guex-Holzer, S. (1954c). Genese der komplexen Kapselstruktur. Schreeiz. Z. Path. 17, 221.

Tomcsik, J. \& Guex-Holzer, S. (1954d). Antikörperproduktion mit isolierter Bakterienzellwand und mit Protoplasten. Experientia, 10, 484.

Tomcsik, J. \& Szongotт, H. (1933). Über ein spezifisches Protein der Kapsel des Milzbrandbazillus. Z. ImmunForsch. 77, 86

Weвв, M. (1948). The action of lysozyme on heat-killed Gram-positive microorganisms. J. gen. Microbiol. 2, 260.

\section{EXPLANATION OF PLATE}

Capsulated Bacillus $\mathbf{M}$ by phase-contrast microscopy. All figures at $\times \mathbf{2 0 0 0}$.

Fig. 1. Indian ink preparation before extraction.

Fig. 2. Indian ink preparation after extraction in a bath of boiling water for $2 \mathrm{hr}$.

Fig. 3. Indian ink preparation after extraction in a bath of boiling water for $4 \mathrm{hr}$.

Fig. 4. A long chain after the addition of homologous serum absorbed with polysaccharide.

Fig. 5. The same chain as in fig. 4 after the addition of non-absorbed homologous serum.

Fig. 6. The same chain as in fig. 5 after the successive addition of anthrax polypeptide antibody. 